\title{
Age estimation using impacted mandibular third molar teeth in Kerala population
}

\author{
R. Heera*, Renu Chandran, S. K. Padmakumar and R. Rajeev
}

\begin{abstract}
Background: The human body becomes disfigured to a great extent so that identification of the individual becomes a challenge. Age determination of unknown human bodies are important in various clinical and scientific disciplines and done by different techniques. Teeth are bestowed with properties of hardness and resilience which makes them important in forensic science. As impacted teeth are least influenced by environmental changes, coronal displacement of cementum in these teeth can be used for estimating age.

Result: One hundred and fifty extracted, intact impacted mandibular third molar teeth, taken from individuals in different regions of Kerala, were ground to the thickness of $25 \mu \mathrm{m}$ to score the coronal displacement of cementum (CDC) in each tooth. Relationship between age and CDC was analysed by linear regression analysis, by making age as dependent variable and CDC as independent variable. Age is derived as Age =2.387 $\times C D C+20.278$.

Conclusions: The present study is a pioneer work to formulate a regression equation to compute age in Kerala population from impacted mandibular third molar teeth using CDC. The results demonstrate that CDC have a statistically significant association with age in Kerala Population and the resultant formulae was different from other previous studies. Thus our observations validate the need for separate formula for computing age using impacted mandibular third molar teeth in Kerala population.

Keywords: Age estimation, Impacted mandibular third molar teeth, Coronal displacement of cementum, Kerala population
\end{abstract}

\section{Background}

Forensic odontology is defined by the Federation Dentaire Internationale as 'that branch of dentistry which, in the interest of justice, deals with the proper handling and examination of dental evidence, and with the proper evaluation and presentation of dental findings (Ashith \& Acharya, 2014). Forensic Age Estimation is an expertise in forensic medicine which aims to define in the most accurate way the chronological age of person of an unknown age involved in judicial or legal proceedings (Schmeling et al., 2011). Dental age (DA) determination is required in various clinical and scientific disciplines in the setting of a crime investigation or a mass disaster because the age at birth, death and year of death as well as gender can guide investigators to the correct identity among a large number of possible matches (Alkass et al., 2010). The human body becomes disfigured to a great extent so

\footnotetext{
* Correspondence: drrenubishnu@gmail.com

Department of Oral Pathology \& Microbiology, Government Dental College Trivandrum, India
}

that identification of the individual becomes a challenge. Teeth are bestowed with properties of hardness and resilience to withstand insults which makes them important in forensic science. Age of an unknown person can be assessed by correlating the physical, skeletal, and dental maturity of an individual. Several methods have been proposed for assessing dental age (Williams, 2001).

Erupted teeth are directly affected by conditions such as mastication, tooth brushing, and by ageing. Impacted teeth remain intact and are only affected by the ageing process (Bocutog \& Yakan, 1997; Azaz et al., 1974). Therefore, impacted teeth are considered suitable for use in research in the effect of ageing on teeth.Coronal displacement of cementum in impacted teeth can be used as an age marker. Study done by Bocutog et al. in 1997 showed that there is a significant linear correlation ween age and coronal displacement of cementum in impacted teeth (Bocutog \& Yakan, 1997). This may be related to continually erupting forces which affect the impacted teeth and may be mechanism by which the 
teeth are protected at the cemento enamel junction. This phenomenon could be used in forensic odontology in age determination.

In a study done by Balwant et al. in 2006 in erupted mandibular third molar teeth, they found that there was no correlation between age and coronal displacement of cementum in erupted teeth because erupted teeth were found to be directly exposed to external environmental factors (Rai et al., 2006).

\section{Methods}

A cross sectional study was conducted in the department of oral pathology and microbiology.

One hundred fifty impacted mandibular third molar teeth were collected from different geographic regions of Kerala and were preserved in separate vials containing $10 \%$ neutral buffered formalin solution.. Teeth with incompletely formed cemento enamel junction and teeth with caries were excluded from the study.

Bucco lingual ground sections were prepared for each tooth collected. Gross reduction of teeth were done in lathe stone till 4 to $5 \mathrm{~mm}$ in thickness followed by manual grinding using an Arkansas stone till the section is $0.25-\mathrm{mm}$ thick. Cleaned and unstained dried sections were mounted on slide using DPX (Distyrene Dibutyl phthalate xylene) with age and sex marked on them. After the preparation of sections, the microscopic analysis was carried out and viewed under 400 magnification using light microscope. Coronal displacement of cementum in micro meters were recorded under low power $(4 \times)$ by means of a micro meter attached to light microscope.

Collected data was statistically analysed using ANOVA test, t-test and Spearman's rank Correlation. Prediction was done by Regression Analysis.

\section{Results}

In the present study, cases were divided into three different age groups from 20 to 40 years. Maximum number of cases belonged to the age group of 21 to 30 years.

In age group of 20 years, the mean value of $C D C$ was $0.46 \pm 0.85$, in age group 21-30 years was $1.96 \pm 1.60$ and in age group $31-40$ years was $4.97 \pm 1.48$. A statistically significant $p$ value of $<0.001$ was observed (Table 1 and Fig. 1).

Table 1 Distribution of data based on age and sex of the individuals

\begin{tabular}{lllll}
\hline Group & Age group (years) & Male & Female & Total number of cases \\
\hline 1 & 20 & 17 & 18 & 35 \\
2 & $21-30$ & 28 & 52 & 80 \\
3 & $31-40$ & 15 & 20 & 35 \\
\hline
\end{tabular}

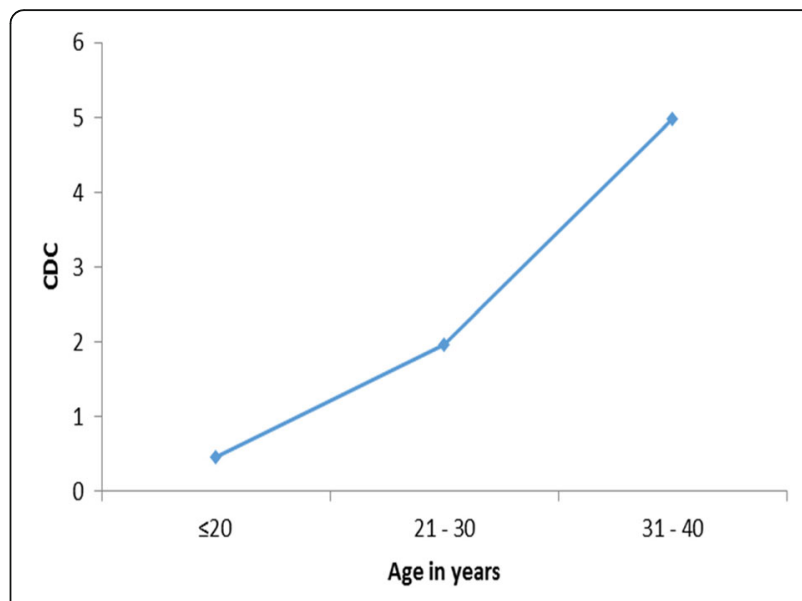

Fig. 1 Comparison of age and mean values of CDC

Relationship between age and CDC was analysed by linear regression analysis, by making age as dependent variable and $C D C$ as independent variable (Table 2 and Fig. 2).

Age was derived as, Age $=\mathbf{2 . 3 8 7} \times \mathbf{C D C}+\mathbf{2 0 . 2 7 8}$.

\section{Discussion}

Teeth are unique in structure and follow a well-defined sequential developmental pattern. Moreover, teeth are most indestructible components of the body because of its resistivity against most of the environmental abuses. Forensic Age Estimation is an expertise in forensic medicine which aims to define in the most accurate way the chronological age of person of an unknown age involved in judicial or legal proceedings

Age estimation using the dentition can be grouped into 3 phases (Azaz et al., 1974). Age estimation in prenatal, neonatal and early postnatal child, age estimation in children and adolescents and age estimation in adults (Pretty, 2003). The principal method of age estimation differs in each age group. Thus choice of method is inherently related to whether unidentified remains are those of a juvenile or an adult, the former being primarily based on developmental, and the latter degenerative, morphological features. So the present study, as it is an invasive method, can be used for age estimation in adults with degenerative features (Franklin, 2010).

To the best of our knowledge, this is the first study to estimate age in Kerala population by scoring coronal

Table 2 Showing relation between age and CDC using regression analysis

\begin{tabular}{llccc}
\hline & $\begin{array}{l}\text { Unstandardized } \\
\text { coefficients }\end{array}$ & $\begin{array}{l}\text { Standardized } \\
\text { coefficient Beta }\end{array}$ & t value & $p$ value \\
\hline Constant & 20.278 & & 51.394 & .000 \\
sCDC & 2.387 & 0.845 & 19.074 & .000 \\
\hline
\end{tabular}




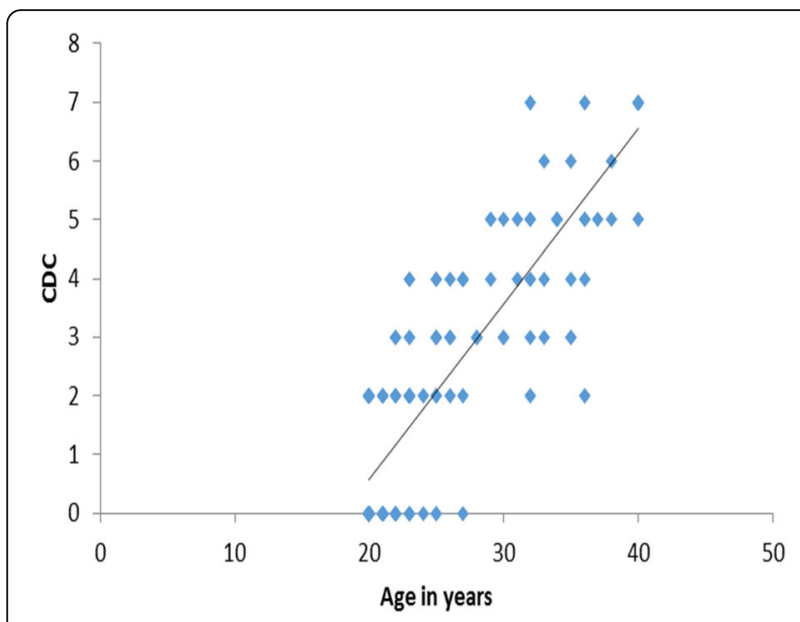

Fig. 2 Showing relation between CDC and age

displacement of cementum in impacted mandibular third molar teeth.

Study done by Bocutog et al. in 1997 showed that there is a significant linear correlation between age and coronal displacement of cementum in impacted teeth (Bocutog and Yakan, 1997). This may be related to continually erupting forces which affect the impacted teeth and may be a mechanism by which the teeth are protected at the cemento enamel junction. In impacted tooth, it was found that as age advances, there is a relative apposition of cementum, coronally. This may be related to continually erupting forces which affect the impacted teeth. As a result of local disruptions in the reduced enamel epithelium that permit follicular cells to come into contact with the enamel surface and differentiate into cementoblasts' such, appositions of cementum on the coronal surface of teeth is possible (Nanci, 2007).

In contradictory to this, a study done by Balwant et al. in 2006 and Raju et al. in 2016 in erupted mandibular third molar teeth, found no significant correlation between age and coronal displacement of cementum in erupted teeth because erupted teeth were found to be directly exposed to external environmental factors (Rai et al., 2006; Raju et al., 2016).

In the present study in Kerala population, the Pearson's correlation coefficient value between known age and coronal displacement of cementum in impacted mandibular third molar was found to be strongly positive with a correlation coefficient of 0.832 and significant at the 0.001 level. This indicate that coronal displacement of the cementum showed significant increase with age. The study done by Sharma et al. and Rai et al. also supported this (Sharma et al., 2010; Rai and Annad, 2009). But this value is superior to the value observed by Bocutog et al. in impacted maxillary canines in Turkish population $(r=0.69)$ (Bocutog and Yakan, 1997). This discrepancy may be due to difference in teeth and the ethnicity of the population studied. However the value obtained from the present study was comparable to the value observed by Rai et al. in impacted mandibular third molar in Nepalese population $(r=0.89)$ (Rai, 2009a). This observations indicated that age and coronal displacement of cementum in impacted teeth also showed a racial difference and validate more studies in different races to establish their influence in coronal displacement of cementum in impacted teeth with increase in age.

In the present study we formulated a regression equation using the scores to estimate age from impacted mandibular third molar teeth in our population.

$$
\text { Age }=2.387 \times \text { CDC }+20.278
$$

There was significant difference between the present regression formula and the previous equation formulated for North Indian Population. This may be attributed to difference in genetic factors, nutritional factors and geographical factors (Rai, 2009b).

The average age difference between known and estimated age in this study was found to be \pm 5.28 years. In forensic cases, an error of \pm 10 years of age is considered as an acceptable range (Talreja et al., 2012). In Gustafson's method the average error was just \pm 3.6 years. However when Pillai and Bhaskar applied Gustafson's method on an Indian population they obtained an average error rate of about \pm 8 years (Ashith and Acharya, 2014).

\section{Conclusion}

Coronal displacement of cementum can be considered as a useful parameter for estimating age from impacted teeth. Our observations validate the need for separate formula for computing age using impacted mandibular third molar teeth in other population and Kerala population. There also exist a racial influence in estimation of age from teeth. Further studies on impacted teeth in wider populations in different races may be of considerable help in making use of impacted teeth as a better and sensitive tool in estimating age in human identification.

\section{Abbreviations \\ CDC: Coronal displacement of cementum; DPX: Distyrene Dibutyl phthalate xylene}

\section{Authors' contributions}

$\mathrm{RH}$ : contributed in definition of intellectual content, literature search, study design, data acquisition, data analysis, manuscript preparation, editing and review. RC: gave valuable contribution in concepts, design of study, literature search, study design, clinical studies, data acquisition, data analysis, statistical analysis, manuscript preparation, editing and review. SKP: contributed in definition of intellectual content, literature search, study design, data acquisition, data analysis, manuscript preparation, editing and review. RR: contributed in definition of intellectual content, literature search, study design, data acquisition, data analysis, manuscript preparation, editing and review. All authors read and approved the final manuscript. 


\section{Ethics approval and consent to participate}

Ethical approval obtained from Institutional Ethics Committee (IEC/C/4/2015/

DCT/dated 05-01-2015), Government Dental College, Thiruvananthapuram.

\section{Consent for publication}

As there is no personal data taken, no consent obtained.

\section{Competing interests}

The authors declare that they have no competing interest.

\section{Publisher's Note}

Springer Nature remains neutral with regard to jurisdictional claims in published maps and institutional affiliations.

Received: 7 December 2017 Accepted: 10 July 2018

Published online: 17 July 2018

\section{References}

Alkass K et al (2010) Age estimation in forensic sciences application of combined aspartic acid racemization and radiocarbon analysis. Mol Cell Proteomics 9(5):1022-1030

Ashith B, Acharya B (2014) Sivapathasundharam. Shafer's Textbook of Ora Pathology, 7th edn. Elsevier, India

Azaz B, Ulmansky M, Moshev R, Sela J (1974 Nov 30) Correlation between age and thickness of cementum in impacted teeth. Oral Surgery, Oral Medicine, Oral Pathology 38(5):691-694

Bocutog Ö, Yakan B (1997 Jun 1) Coronal displacement of cementum: correlation between age and coronal movement of cementum in impacted teeth. Aus Den J 42(3):185-188

Franklin D (2010) Forensic age estimation in human skeletal remains:current concepts and future directions. Leg Med (Tokyo) 12(1):1-7

Nanci A (2007) Ten cate's oral histology: development, structure, and function, 8th edn. Elsevier Health Sciences, India

Pretty IA (2003 Sep 1) The use of dental aging techniques in forensic odontological practice. J Forensic Sci 48(5):1127-1132

Rai B (2009a Jan 31) Coronal displacement of cementum in impacted teeth: as age marker. J Forensic and Legal Med 16(1):5-6

Rai B (2009b Jan 1) Effect of nutrition on coronal displacement of cementum in impacted teeth. Ann Human Bio 36(4):431-436

Rai B, Annad SC (2009 May 1) Accuracy of BR regression equation for impacted teeth in age estimation in Haryana population of India. J Forensic Sci 54(3):662-663

Rai B, Dhattarwal SK, Bhardwaj DN, Anand SC (2006) Coronal displacement of cementum in impacted teeth in age determination. World J Med Sci 1(2):93-94

Raju GS, Keerthi M, Nandhan SR, Rao TM, Kulkarni PG, Reddy DS (2016 Sep) Cementum as age determinant: A forensic view. J Forensic Dent Sci 8(3):175

Schmeling A, Prieto JL, Landa MI, Garamendi PM (2011) Forensic medicine from old problem to new challenge. 2nd edn. Intech Open Access Publisher, London

Sharma AT, Chaudhary M, Thombre V, Tekade SA, Pradhan P, Bagri K (2010) Coronal displacement of cementum in impacted teeth and its correlation to age: a preliminary study. J Ind Acad Oral Med and Radiol 22:190-192

Talreja PK, Acharya AB, Naikmasur VG (2012) An assessment of versatility of Kvaal's method of dental age estimation in Indians. Arch Oral Biol 57(3):277-284

Williams $\mathrm{G}$ (2001) A review of the most commonly used dental age estimation techniques. J Forensic Odontostomatol 19:9-17

\section{Submit your manuscript to a SpringerOpen ${ }^{\circ}$ journal and benefit from:}

- Convenient online submission

- Rigorous peer review

- Open access: articles freely available online

High visibility within the field

- Retaining the copyright to your article

Submit your next manuscript at $\boldsymbol{\nabla}$ springeropen.com 